\title{
The preliminary study on inverted problem-based learning in biology among science foundation students
}

\author{
Azlinah Matawali, Sitty Nur Syafa Bakri, Nur Ramziahrazanah Jumat, Iziana Hani Ismail, \\ Sazmal Effendi Arshad, Wardatul Akmam Din \\ Preparatory Centre for Science and Technology, Universiti Malaysia Sabah, Malaysia
}

\begin{tabular}{l}
\hline \hline Article Info \\
\hline Article history: \\
Received Aug 20, 2019 \\
Revised Oct 25, 2019 \\
Accepted Nov 30, 2019 \\
\hline
\end{tabular}

Keywords:

Mitosis

Meiosis

Problem-based learning

Science foundation

Universiti Malaysia Sabah

\begin{abstract}
The emergent of Science, Technology, Engineering and Mathematics (STEM) Education in Malaysia has embarked challenges in higher education system. Conventional teaching methods often cause lower learning gain, fear and bad perceptions among sstudents. The old initiative may also be the cause of students' demotivation, lower interest in learning a subject or even dropouts. This study was conducted to evaluate the effectiveness of an inverted classroom by using the problem-based method in Biology subject among science foundation students. Students were divided into two groups; experimental (EG) and control (CG) group. A topic in Biology had been selected, and an assessment paper was given to both groups before and after the intervention session. The EG would experience self-learning through given materials and asked to conduct a problem-based learning study case. Meanwhile, the CG would obey the conventional teaching method before given a similar study case. The result reported significant improvement in assessment marks for EG group compared to the CG group. The students' comparison between the pre- and post-test implies that they have shown positive improvement in understanding the content of the subject tested. This finding will serve as a primary platform to improvise and enhance teaching and learning methodology in biology subject for foundation level.
\end{abstract}

Copyright (C) 2019 Institute of Advanced Engineering and Science. All rights reserved.

\section{Corresponding Author:}

Azlinah Matawali,

Preparatory Centre for Science and Technology,

Universiti Malaysia Sabah,

UMS Street, 88400 Kota Kinabalu, Sabah, Malaysia.

Email: azlinah@ums.edu.my

\section{INTRODUCTION}

Conventional teaching strategies become apparent to be teacher-centred and discipline-centred. The needs, concerns, and requirements of both the teachers and students are not considered following the disciplined-centred teaching. Science teaching does not only require the attention of the course but also concerns the value of student input in understating the process of moving students from their initial state of knowledge and understanding to the desired level. Increasing interest in learner's individual differences had developed due to the change from the traditional teacher-centred to student-centred approach [1]. Besides, the academic achievement of students is also known to be directly influenced by individual differences. Awareness of learning styles and their roles in academic achievement can benefit educational psychologists, teachers and researchers [2].

The emergent of Science, Technology, Engineering and Mathematics or STEM implementation in education has been emphasized in the Malaysian Education Development Plan (MEDP) 2013-2015 to prepare students for $21^{\text {st }}$ century challenges. However, various studies reported on difficulties faced by students in learning Biology. Genetic related topics, such as mitosis and meiosis, genes and chromosomes, and Mendelian genetics, are among the topics in Biology considered hard to understand by students. Main 
reasons for the learning difficulties are due to the nature of the topic, teachers' style of teaching, and students' learning styles and attitude toward the topic. Hence, more practices in making Biology learning interesting should be promoted not only to overcome the challenges but also to improve Biology learning among students [3-5].

In contrast with the traditional class settings, flipped classroom is a pedagogical approach which inverts the conventional notion of the classroom-based learning. Students are introduced with topic materials before the class, with the classroom time then being used to demonstrate an active learning activity, mainly problem-based learning activities. To fill the gap regarding the shifting nature of teacher- to student-centred approach, these activities are conducted with the assistance of instructors to clarify unfamiliar concepts, resolve the problems, or pose new questions. Introducing the content of the topic involves video lectures and readings. Hence, this model increases the interaction between the instructor and students during class and transfers the learning responsibility and ownership to the students instead of by participating in interactive activities [6, 7].

Integrating flipped classroom with the problem-based learning in STEM related education does suggest that the students' learning styles have not only improved, but it may have substantial influences on their academic performance [8-12]. Unfortunately, study focusing mainly on the effectiveness of flipped classroom in Biology teaching on foundation students is still limited. Hence, the objective of the current study is to investigate the effectiveness of inverted problem-based learning classroom (IPBLC) approach in Cell Division topic covered in Cell Diversity, Reproduction, Ecology and Development (SB0014) course. This current study is also carried out to compare the academic performance between the control and experimental groups of science foundation students after exposing them to different learning styles, respectively.

\section{RESEARCH METHOD}

\subsection{Study design}

A total of 75 pre-university students from the Preparatory Centre of Science and Technology, University Malaysia Sabah participated in this study. They were then being assigned into 2 groups equally to facilitate the classroom activities with different approaches; the Experimental group experienced a flipped classroom (FC), integrated with the problem-based learning (FC-PBL) while the Control with the traditional teaching methods $(\mathrm{T})$ with the problem-based learning (T-PBL). All the participants had first experienced the FC-PBL and T-PBL for two sessions, only then to be randomly assigned to the control and experimental groups. In experimental treatment, the researcher physically intervened to alter the conditions experienced by the EG (e.g., they were provided with online resources including recorded lectures, theoretical slides, chapter exercises and quizzes as well as chat room discussion with their lecturers during the FC session). The other group received a lecture - the traditional form of instruction in the class of the similar topic for a two-hour session. Theoretical slides and exercises were provided to this group during the class period. The PBL was conducted to assess the students' understanding toward the topic learned after the experimental treatment, thus both groups were tested with an identical problem and expected to present their findings at the end of the sessions with only a team of five in each group.

\subsection{Data collection}

In this experiment, the statistical comparisons were utilized among the two groups on each of the two tests; the pre- and post. The CG and EG received the pre-tests before the researchers manipulated the treatment conditions. The post-tests were then administered to assess the students' understanding on the selected topic after the PBL session ended. Both tests were similar in question and consistent in format. The pretest-posttest comparison would evaluate the effect of different teaching methods, thus manifested through the academic performances of the students in the post-test. Beforehand, a survey was conducted to all the participants to address the Biology grades scored during the O-level examination or prominently known as Sijil Pelajaran Malaysia (SPM).

\subsection{Data analysis}

A Mann-Whitney U test was used to analyse the difference of mean scores for pre-test and post-test of EG and CG respectively. A statistical software package, SPSS version 23, was used for the analysis and statistical significance was set at Sig. value $<0.05$. 


\section{RESULTS AND DISCUSSION}

\subsection{Samples background}

"People factor" may introduce threats that influence the outcome, such as selecting individuals who are brighter or more receptive to a treatment for the EG. Thus, conducting a survey to identify individual Biology grades scored for the Sijil Penilaian Malaysia (SPM) exam could rule out this factor which might influence the outcome of this experiment. The students, who randomly assigned to the control and experimental groups, both showed normal distribution curve which implied that their abilities in Biology subject were evenly distributed and there was not any obvious bias factor in term of student selection.

Figure 1 shows the distribution of students' Biology grades for SPM 2017. Of the 31 students from the CG, students' grade is in descending order; $B+>A->B>C+>A>A+>C$. On the other hand, 16 students from the $\mathrm{EG}$ group scored $\mathrm{B}+$. Grading for $\mathrm{EG}$ group is as following descending order; $\mathrm{B}+>\mathrm{A}-$ $>\mathrm{B}>\mathrm{C}+>\mathrm{A}>\mathrm{A}+>\mathrm{C}+$. Thus, the sample study is proven to be well distributed based on the data collected.

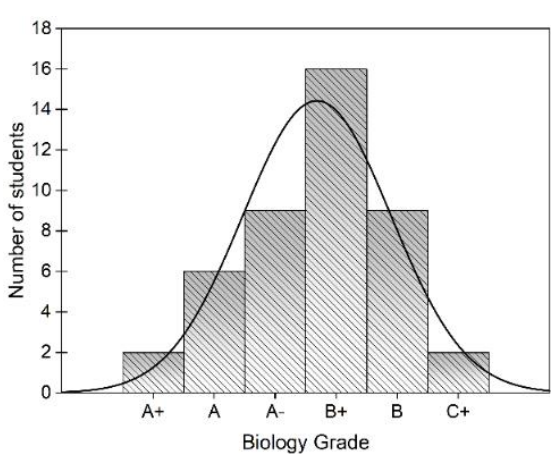

(a)

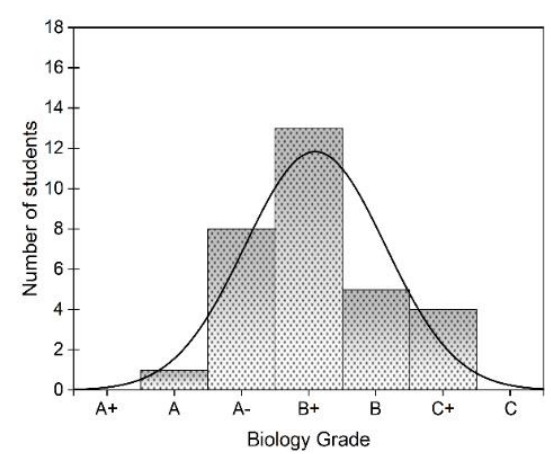

(b)

Figure 1. Normal distribution graphs on both

(a) Experimental group (b) Control group

\subsection{Intervention using IPBLC method}

To answer the research question dealing with the effectiveness of the flipped classroom on the students' academic performance, the chapter of Cell Division designed for the college foundation level was selected. Cell cycle, mitosis, meiosis, and application in cell division were among the content of this chapter. The participants were asked to answer two sets of questions (the pre- and post-test) before and after the intervention period. Two Biology lecturers holding Master's and $\mathrm{PhD}$ degrees teaching Biology subject with a minimum teaching experience of three years rated the samples. The Mann-Whitney U Test was employed for the data analysis and Figure 2 shows the mean between the students' pre-test and post-test scores. There was a significant improvement observed in the EG as the mean marks increased from $21.53 \pm 4.15$ to $25.64 \pm 3.42$ after post-test. Furthermore, the dip in standard deviation value demonstrates an improved consistency of the mean marks. Like the EG, the mean difference between the two test scores of the CG also indicated a positive improvement, although the value was still significantly lower than the EG. As the Figure indicates, there was 3.6613 points increment only from the pre-test, with slightly increased standard deviation values which implied the less consistencies of the marks received by students.

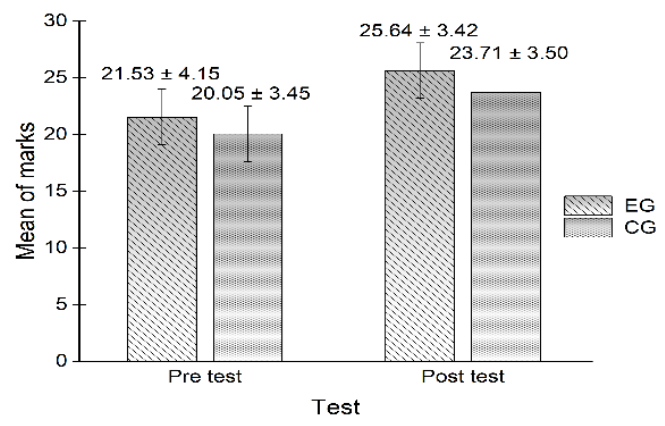

Figure 2. Average marks between EG and CG after implementation of IPBLC method 
In biology, students' performance in few challenging topics had been well-studied for example in cell division, organelles, genetic inheritance, DNA replication concept, cloning, plant tissue culture and osmosis [13-18]. Some of the misconceptions about Biology subject had also been identified, such as in Mendelian genetic, Cell life cycle and Reproduction [19-20]. In Cell Division topic, students usually found it challenging to grasp the conceptual understanding about sexual and asexual concepts, mitosis and meiosis processes, chromosomal mechanics and later expanding their knowledge in Cell Division to Mendelian Genetics [19]. The common preconception about cell division is complicated and problematic as well as all the misconceptions reported earlier. The common preconceptions made this topic interesting to be assessed among the pre-university students at Universiti Malaysia Sabah.

As the conventional teaching method had less impressive impact to overcome the misconception [21], attempting to integrate active learning strategies into the lessons could be highly beneficial for the learners. Implementing active learning into Biology course had been extensively studied to increase the learning outcomes among students compared to traditional chalk and talk method [15]. One of the strategies in active learning for biology subject is through problem-based learning [22]. Inverted classroom, primarily through a case study or problem-based learning had contributed to the increasing number of students' learning gains in biology subject [17, 23]. Students work in groups to solve the real complex scenarios using their previous knowledge thought in class through independent discovery and inquiry-based format. In this study, students had been given a case study that urged them to apply all concepts that were learned in Cell Division topic. Hence, this justifies the selection of cell division topic and inverted classroom in the form of problem-based learning as the assessment topic and teaching method in this study, respectively.

In terms of methodological approach, another research had been published assessing this Cell division topic among students using various Computer-Mediated Simulation module [24, 25]. In these modules, the experimental group also shows significant increase scores during pretest-posttest evaluation. However, the development and execution of the module was quite difficult, involving more tools or facilities such as computers, and some module was restricted to IBM compatible computers only.

Therefore, as indicated by the data analysis in this research, the intervention using IPBLC method in Cell Division have built up a positive impact which was manifested through their performance in the tests. The result of this study was by the assessment reported by [17]. This paper had evaluated Cell Division subject especially mitosis and meiosis topics, and the results were found in line with Figure 2. Unlike [17], which reported about $16.0 \%$ increment of mean score between the control and experimental groups, the analysis derived from this study was only about $13.7 \%$ increment.

However, this finding still revealed a significant improvement in the students' academic performance and comprehension, thus encourages educators and test practitioners to provide more effective educational tools for an effective students' engagement in the classroom.

\section{CONCLUSION}

Inverted problem-based learning classroom (IPBLC) method has proven to improve students' achievements among Science Foundation students at the University of Malaysia Sabah. To further elaborate on the effectiveness of this method, a series of survey on students' perception should be conducted to define the correlation between learning gains with students' performance in the tests. Hence, the validity of the results also could be enhanced by using variety and more challenging topics in Biology subject. For instance; Gene and DNA, Mendelian genetics and Biochemistry.

\section{ACKNOWLEDGEMENTS}

This work was supported by the University of Malaysia Sabah Research Grant Scheme (SGPUMS) from Universiti Malaysia Sabah (SBK 0294-SSI-2016). The authors also would like to acknowledge the assistance and guidance from Ms. Elnetthra Folly Eldy (Universiti Malaysia Sabah) throughout the research.

\section{REFERENCES}

[1] Etorbo, A. B. \& Fabinu, E, "Students' perceptions of difficult concepts in Biology in Senior Secondary Schools in Lagos State," Global Journal of Educational Research, vol. 16, pp. 139-147, 2017.

[2] Al Zoubi, S. M. \& Younes, M. A. B, "Low Academic Achievement: Causes and results," Theory and Practice in Language Studies, vol. 5, no. 11, pp. 2262-2268, 2015.

[3] Tekkaya, C., Ozkan, O. \& Sungur, S, "Biology concepts perceived as difficult by Turkish High School Students," Hacettepe Univ. J. Educ., vol. 21, pp. 145-150, 2001.

[4] Çimer, A, "What makes biology learning difficult and effective: Students' views?," Educational Research and Review, vol. 7, no. 3, pp. 61-71, 2012. 
[5] Ab Wahid, N. T. \& Talib, O, "Stem integration in classroom practices among biology teachers in Mara Junior Science College (MJSC)," International Journal of Academic Research in Business and Social Sciences, vol. 7, no. 4, pp. 1030-1041, 2017.

[6] Pierce, R. \& Fox, J, "Vodcasts and active-learning exercises in a "Flipped Classroom" model of a renal pharmacotherapy module," American Journal of Pharmaceutical Education, vol. 76, no. 10, pp. 196, 2012.

[7] Olson, R, "Flipping engineering probability and statistics- lessons learned for faculty considering the switch," 2014 ASEE Annual Conference \& Exposition, Indianapolis, Indiana. [Online] Available: http://peer.asee.org/20507. [Accessed Sep 2019].

[8] Atwa, Z., Din, R. \& Hussin, M, "Effectiveness of Flipped classroom in Physics education on Palastinian High School Students' achievement," Journal of Personalized Learning, vol. 2(1), pp. 73-85, 2016.

[9] Luo, J., Lin, T., Zou, Y., Liu, X., Zuo, C. \& Zhong, Y, "Integrating a flipped classroom and problem-based learning into ophthalmology education," Yan Ke Xue Bao, vol. 32(1), pp. 25-32, 2017.

[10] Prasetyo, B. D., Suprapto, N. \& pudyastomo, R. N.,"The effectiveness of flipped classroom learning model in secondary physics classroom setting," Journal of Physics: Conference Series, vol. 997, pp. 012037, 2018.

[11] Lee, C. \& Kim, S. W., "Effectiveness of a Flipped classroom in learning periodontal diagnosis and treatment planning," Journal of Dental Education, vol. 82(6), pp. 614-620, 2018.

[12] Leong, J. S., Canada-Canada, F. \& Gonzalez-Gomez, D.,"The study of Flipped-Classroom for pre-service scence teachers," Education Sciences, vol. 8(163), 2018.

[13] Bowling, B. V., Acra, E. E., Wang, L., Myers, M. F., Dean, G. E., Markle, G. C., Moskalik, C. L., \& Heuther, C. A, "Development and evaluation of genetics literacy assessment instrument for undergraduates," Genetics Society of America, vol. 178, pp. 15-22, 2008.

[14] Smith, M. K., Wood, W. B., \& Knight, J. K, "The genetics concept assessment: A new concept inventory for gauging student understanding of genetics," CBE- Life Science Education, vol. 7, pp. 422-430, 2008.

[15] Morevac, M., Williams, A., Anguilar-Roca, N., \& O'Dowd, D. K, "Learn before lecture: A strategy that improves learning outcomes in a large introductory biology class," CBE-Life Science Education, vol. 9, pp. 473-481, 2010.

[16] Ables, E. T, "Drosophila oocytes as a model for understanding meiosis: An educational primer to accompany "Corolla is a novel protein that contributes to the architecture of the synaptonemal complex of Drosophilla"," Genetics Society of America, vol. 199, pp. 17-23, 2015.

[17] Bonney, K. M, "Case study teaching method improves student performance and perceptions of learning gains," Journal of Microbiology and Biology Education, vol. 16(1), pp. 21-28, 2015.

[18] Masnoddin, M., Kiram, J. J., Matawali, A., \& Jumat, N. R, "Improving pre-university students' understanding of basic plant tissue culture topic through laboratory teaching: A case study of UMS," Transection on Science and Technology, vol. 5(1), pp. 53-57, 2018.

[19] Luksa, Z., Radanovic, I., Garasic, D., \& Sertic Peric, M. "Misconceptions of primary and high school students related to the biological concept of human reproduction, cell life cycle and molecular basis of heredity," Turkish Science Education, vol. 13(3), pp. 143-160, 2016.

[20] Awang Kanak, F., Masnoddin, M., Matawali, A., Daud, M. A., \& Jumat, N. R, "Difficulties experienced by science foundation students on basic Mendelian genetics topic: A preliminary study," Transactions on Science and Technology, vol. 3(1-2), pp. 283-290, 2016.

[21] Bahar, M, "Misconceptions in biology education and conceptual change strategies," Educational Sciences: Theory \& Practice, vol. 3(1), pp. 55-64, 2003.

[22] Allen, D. \& Tanner, K, "Infusing active learning into the large-enrolment biology class: Seven strategies, from the simple to complex," Cell Biology Education, vol. 4, pp. 262-268, 2005.

[23] Anderson, W. L., Mitchell, S. M., \& Osgood, M. P, "Comparison of student performance in cooperative learning and traditional lecture-based biochemistry classes," Biochemistry and Molecular Biology Education, vol. 33(6), pp. 387-393, 2008.

[24] Wekesa, D. W., Wekesa, E. W., \& Amadalo, M. M, "A computer mediated simulation module for teaching cell division in secondary school biology," International Jurnal of Educational Research and Development, vol 2(5), pp. 114-130, 2013.

[25] Kiboss, J. K., Ndirangu, M., \& Wekesa, E. W, "Effectiveness of a computer-mediated simulations program in school biology on puoils' learning outcomes in cell theory," Jurnal of Science Education nd Technolog, vol 13(2), pp. 207-213, 2004.

\section{BIOGRAPHIES OF AUTHORS}

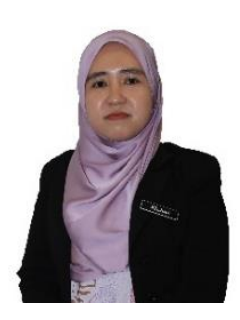

Azlinah Matawali is currently a Biology lecturer at Preparatory Centre for Science and Technology, Universiti Malaysia Sabah, Malaysia. Her interests are majoring in natural product biotechnology, cell biology and cell signalling interaction, as well as biology education for college student using inverted classroom technique. 


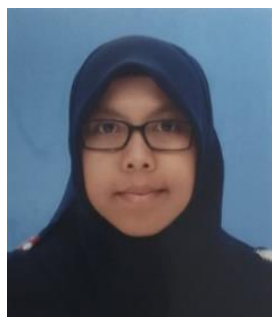

Sitty Nur Syafa Bakri is a Biology lecturer that attached to Preparatory Centre for Science and Technology (PPST), Universiti Malaysia Sabah, Sabah, Malaysia. She is experience in teaching Biology for foundation student for almost 10 years. Recently, she and her team are actively involved in applying blended learning in teaching Biology including flip classroom and online medium such as moodle (Smart2ums) for SB0014 - cell diversity, reproduction, ecology and development, SB0024- physiology and genetic, SB0011 and SB0021- practical for biology.

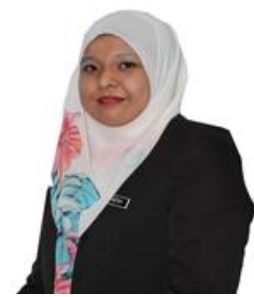

Nur Ramziahrazanah Jumat is a Biology lecturer attached to Preparatory Centre for Science and Technology, Universiti Malaysia Sabah, Malaysia. Her interest and expertise cover the area of immunobiology, immunological regulation, medical biotechnology and as well as biological education for foundation students.

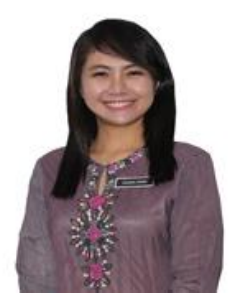

Iziana Hani Ismail is an English teacher attached to Preparatory Centre for Science and Technology, Universiti Malaysia Sabah, Malaysia. She is currently pursuing her master study in Teaching English as Second Language (TESL) at Universiti Malaysia Sabah.

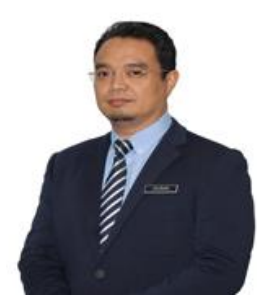

Sazmal Effendi Arshad completed his PhD at Sheffield University, UK. He has been working as lecturer at Faculty of Science and Natural resources. Currently he holds the position as Director at Preparatory Centre for Science and Technology, Universiti Malaysia Sabah, Malaysia. His expertise and interest include materials engineering, solid state chemistry and biopolymers.

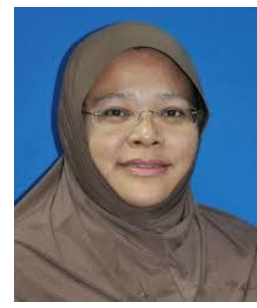

Wardatul Akmam Din completed her PhD at Universiti Utara Malaysia in Applied Linguistics. She works as English lecturer at Preparatory Centre for Science and Technology, Universiti Malaysia Sabah, Malaysia. 